\title{
Hubungan Iklan Produk Kecantikan Di Televisi Dengan Orientasi Tubuh Wanita Bekerja
}

\author{
RelationshipsOfAdvertising On Television With Beauty Products Women's Body of Career \\ Women
}

\author{
Lidia Astuti ${ }^{1}$, Siti Amanah ${ }^{2}$ \\ ${ }^{1}$ Departemen Sains Komunikasi dan Pengembangan Masyarakat FEMA IPB \\ ${ }^{2}$ Dosen Departemen Sains Komunikasi dan Pengembangan Masyarakat FEMA IPB
}

\begin{abstract}
Fast along itstechnological growth and information, media placed by as one of factor with the biggest influence in image forming in society. The study aims to: (1) analyze the characteristic of woman worker in rural and urban areas; (2) analyze relation between characteristics individual with body oriented of women worker; (3) analyze relation the relationship between the sociological environment with body oriented of women worker. The research uses survey method and was conducted in Menteng, Bogor Barat Subdistrict and Cihideung Udik Bogor City. Numbers of samples are 60 respondents. Descriptive and correlational analysis was used to explain this research. The results of the research show that: women worker in rural and urban areas have diferences characterstic individual. This difference seen from the age of respondents, formal education level, beauty of lifestyle, activity work, and family income
\end{abstract}

Keyword : Advertisement, Ideal Body of Woman, Orient Body.

\begin{abstract}
Abstrak
Perkembangan teknologi dan informasi media merupakan salah satu faktor besar yang mempengaruhi pembentukan gambaran dalam masyarakat. Penelitian ini bertujuan untuk: (1) menganalisis karakteristik dari wanita pekerja di pedesaan dan perkotaan; (2) menganalisis hubungan antara karakteristik individu dengan orientasi tubuh wanita bekerja; (3) Menganalisis hubungan antara lingkungan sosiologis dengan orientasi tubuh wanita bekerja. Penelitian ini menggunakan metode survey dan dilaksanakan di Menteng, Kecamatan Bogor Barat dan Cihideung Udik Kota Bogor. . Jumlah sampel penelitian ini adalah 60 orang. Metode analisis yang digunakan adalah deskriptif dan korelasi. Kesimpulan penelitian ini adalah Wanita bekerja di wilayah perkotaan dan pedesaan memiliki karakteristik individu yang berbeda. Perbedaan ini dilihat dari usia responden, tingkat pendidikan formal, gaya hidup akan kecantikan, aktifitas pekerjaan, dan pendapatan keluarga
\end{abstract}

Kata kunci: Iklan, Tubuh ideal perempuan, Orientasi tubuh

\section{Pendahuluan}

Sebuah pencitraan adalah sebuah persepsi atau gambaran dalam masyarakat yang dibentuk dan diproses dari suatu realitas yang beranjak dari kenyataan, kemudian dibungkus dalam suatu abstraksi yang diberi makna. Menurut Bachtiar (2008) mengemukakan pencitraan adalah karya kreatif yang dibalut dengan berbagai teknik persuasi yang hasilnya menampilkan sesuatu yang lebih menarik dan meyakinkan. Pencitraan terbentuk dengan rancangan argument untuk mengubah persepsi masyarakat untuk mempercayai suatu hal. Sebuah pencitraan dalam sebuah masyarakat dapat terbentuk oleh berbagai faktor, diantaranya adalah faktor budaya yang berkembang, faktor kebiasaan yang telah berakar dan faktor media yang berperan sebagai salah satu alat komunikasi dan informasi di masyarakat. pembentukan pencitraan dalam masyarakat adalah iklan. Rasyid (2005) mengatakan iklan merupakan suatu bentuk dari komunikasi yang secara tipikal mencoba untuk membujuk konsumen 
yang potensial untuk membeli atau mengkonsumsi lebih dari suatu merek atau jasa tertentu. Dalam hal ini iklan membawa misi penting yaitu sebagai sarana pemasaran suatu produk atau jasa yang bersifat persuasi. Oleh karena itu, banyak periklanan dirancang untuk meningkatkan konsumsi akan produk dan pelayanan melalui proses peneguhan atau meyakinkan akan suatu brand image.

Perkembangan dunia yang semakin modern, kecantikan menjadi komuditas yang diperdagangkan, sehingga perempuan seolah tak punya pilihan untuk mendifinisikan kecantikannya sendiri. Berbagai macam produk kecantikan-pun semakin banyak dipasaran. Melalui iklan di televisi, produsen membentuk gambaran bagaimana sebaiknya wanita berpakaian dan berprilaku untuk mendapatkan penghargaan dari masyarakat dan juga lawan jenisnya. Melalui iklan juga dibentuk kriteria wanita cantik seperti apa yang sedang berlaku di masyarakat, dan bagaimana cara mereka yang tidak masuk kriteria tersebut (tidak cantik) mengatasi masalahnya. Dorongan dari pihak luar juga senantiasa menginjeksikan citra pentingnya penampilan memikat, cantik, mempesona, sensual, dan agar tampak muda pada wanita (Arief, 2001). Ketidakpuasan terhadap tubuh yang besar menyebabkan makin kuatnya keinginan para perempuan untuk melakukan segala cara demi memperbaiki penampilan fisiknya (Munfarida, 2007). Banyaknya perempuan yang mengalami ketidakpuasan terhadap sosok tubuhnya pada saat ini disebabkan adanya kesenjangan tubuh ideal yang didasarkan pada budaya yang saat ini berlaku, yaitu bahwa tubuh ideal bagi perempuan adalah yang langsing, dengan kenyataan tubuh yang mereka miliki saat ini, yaitu bahwa kebanyakan perempuan memiliki tubuh yang lebih gemuk atau sedikit melebihi standar. Majalah atau iklan kecantikan yang menampilkan model tubuh langsing menyebabkan perempuan mengalami body image dilemma. Dilema citra tubuh sering tidak disadari, sehingga timbul kesenjangan antara bentuk tubuh yang diinginkan dan persepsi mengenai bentuk tubuhnya sendiri yang menyebabkan kebingungan dan rasa sakit pada pikiran banyak perempuan (Crook,1991 dalam Goenawan, 2007) .

Wanita metropolis dari kalangan menegah dan atas lebih banyak terpapar iklan atau media massa (Andika, 2008) serta strategi kapitalis yang memang lebih ditujukan bagi mereka, sehinga wanita metropolis lebih mudah mengalami citra tubuh negatif karena adanya kesenjangan antara citra tubuh ideal dengan citra tubuh nyata (Melliana, 2006). Tersedianya fasilitasfasilitas dan keadaan finansial yang cukup memadai juga mengakibatkan mereka lebih banyak waktu dan perhatian untuk memikirkan dan menghayati tubuhnya sendiri, serta melalukan usaha untuk memperbaiki. Berbeda lagi dengan wanita dari kalangan sosial ekonomi bawah. Berdasarkan latar belakang yang sudah disebutkan di atas, maka penelitian ini akan difokuskan untuk mengkaji sejauhmana "Hubungan antara Iklan Produk Kecantikan dengan Orientasi Tubuh Wanita Bekerja Perkotaan dan Pedesaan".

\section{Metodologi Penelitian}

Penelitian ini menggunakan pendekatan kuantitatif didukung pernyataan secara kualitatif. Metode kuantitatif dilakukan dengan metode survai, yaitu penelitian yang mengambil sampel dari populasi dan menggunakan kuesioner sebagai alat pengumpul data primer, dengan individu sebagai unit analisa (Singarimbun, 1995)

Data kuantitatif diperoleh dengan melakukan wawancara terstruktur yang dipandu dengan kuesioner. Pernyataan kualitatif digunakan untuk menambah keakuratan data ketika proses pengumpulan data secara kuantitatif berlangsung. Penelitian dilaksanakan di Desa Cihideung Udik dan Kecamatan Menteng Kota Bogor. Pengambilan data lapangan dilakukan pada bulan Juni-Juli 2009. Populasi sampling dalam penelitian ini adalah seluruh wanita bekerja di Kelurahan Menteng, Kecamatan Bogor Barat, dan Desa Cihideung Udik Kota Bogor, Propinsi Jawa Barat. Responden dipilih dengan metode 
pengambilan sampel acak sederhana (simple random sampling) responden penelitian ini berjumlah 60 orang.

Data primer yang berupa data kuantitatif dalam penelitian ini diperoleh dengan menggunakan kuesioner yang berisi pertanyaan untuk diajukan kepada responden. data kualitatif dikumpulkan dengan cara wawancara mendalam untuk mengetahui lebih lanjut hubungan iklan produk kecantikan terhadap orientasi tubuh secara lebih langsung dan mendalam. Data

\section{Hasil Dan Pembahasan}

\section{Gambaran Umum Responden \\ Responden Wanita Bekerja Wilayah Pedesaan}

Wanita Bekerja yang menjadi responden pada penelitian kali ini adalah wanita yang telah mempunyai penghasilan sendiri untuk mencukupi keperluannya dan berada di wilayah pedesaan. Wilayah tempat tinggal responden berada di Desa Cihideung Udik Kabupaten Bogor khususnya bertempat tinggal di RW 10. Semua responden dalam penelitian ini bekerja di sektor pertanian dan semuanya telah menikah. Pekerjaan mereka adalah buruh tani setengah hari. Alasan mereka bekerja antara lain untuk mencukupi perekonomian keluarga. Upah atau bayaran yang mereka terima sekitar Rp. 10.000,00 untuk setiap harinya, sehingga dalam sebulan mereka dapat mengumpulkan Rp. 300.000,00. Sedangkan para suami yang umumnya juga bekerja sebagai petani menerima upah sebesar Rp. 25.000,00 perharinya, atau Rp.750.000,00 dalam sebulannya.

Sebagian besar responden mempunyai tempat berkumpul untuk berinteraksi sosial seperti pengajian, arisan maupun hanya tempat-tempat bersantai di tepi sawah. Waktu berkumpul responden untuk berinteraksi dengan teman-temannya yaitu siang sampai sore hari. Berbicara mengenai penampilan, responden wilayah pedesaan cenderung berpenampilan apa adanya. Cara mereka menjaga penampilan sekunder diperoleh melalui kelurahan dan kantor desa, literatur-literatur, catatancatatan, dan data-data dari instansi yang dapat mendukung kelengkapan informasi

Data yang diperoleh dianalisis secara kuantitatif dan kualitatif. pengolahan data dilakukan dengan menggunakan program komputer SPSS for Windows versi 16.0 yakni dengan Korelasi Rank Spearman, Uji Mann Whitney dan uji Chi Square.

biasanya dengan membeli produk kosmetika sesuai kemampuan serta meminum jamu tradisional. Iklan produk kosmetika yang paling mereka sukai umumnya pelembab muka yang biasanya menampilkan alur cerita dalam iklannya.

\section{Responden wanita Bekerja Wilayah Perkotaan}

Wanita yang menjadi responden di wilayah ini bertempat tinggal di Kelurahan Menteng Kota Bogor, tepatnya di RW 19. Alas an lokasi ini menjadi tempat penelitian karena sebagian besar wanita mempunyai pekerjaan dan kawasan ini juga merupakan perumahan real estate. Pekerjaan para wanita di Kelurahan Menteng Kota Bogor sangat beragam, antara lain perawat, pegawai negeri sipil, asisten notaries biro jasa, sekretaris, marketing, wirausaha, pegawai swasta sampai kepala bagian keuangan. Penghasilan yang mereka perolehpun sangat beragam, pendapatan terkecil Rp.1.500.000,00 sampai yang terbesar Rp.10.000.000,00 perbulannya. Responden wilayah ini bekerja selain untuk membantu perekonomian keluarga juga sebagai tanda aktualisasi diri dan investasi di masa depan. Serta semua responden dalam penelitian ini sudah menikah.

Responden bekerja dari hari senin sampai jumat pukul 07.00- 17.00 WIB, dan sebagian responden bekerja di wilayah Jakarta, sehingga waktu untuk berkumpul bersama keluarga maupun berinteraksi sosial dilaksanakan hari sabtu dan minggu. Jenis kelompok sosial yang mereka ikuti adalah 
arisan, pengajian, koperasi, posyandu, maupun kelompok senam. Kebanyakan responden wilayah perkotaan jarang menyaksikan iklan di televisi tiap harinya, alasannya tidak cukup waktu maupun bosan. Tetapi beberapa responden juga mengangap menonton televisi sebagai obat penghibur. Iklan produk kecantikan yang disukai wanita perkotaan umumnya sama dengan wanita pedesaan, alasannya suka dengan ide jalan cerita, model yang cantik, maupun memang memakai produk yang ditawarkan. Mengenai hal penampilan pun, para responden wanita bekerja mementingkan sekali aspek penampilan. Penggunaan make up dirasa sudah menjadi kebutuhan untuk tampil menarik, baik digunakan sewaktu bekerja maupun ketika berhubungan dengan masyarakat atau publik. Para wanita bekerja perkotaan menjaga penampilannya dengan rajin dating ke salon kecantikan, untuk facial, manicure pedicure, spa, sauna, hair treatment, full body treatment, pemijatan, refleksi maupun mengubah warna dan bentuk rambut. Selain itu, sebagian responden mengunjungi tempat kebugaran seperti senam, maupun fitness untuk tetap menjaga tubuh tetap prima dan langsing. Wanita bekerja diperkotaan-pun memiliki dokter kecantikan tertentu agar terlihat awet muda, langsing, putih maupun terawat. Bahkan salah satu responden melakukan operasi kecantikan seperti suntik kurus (suntik aquapuntur) maupun sedok lemak di dokter kecantikan.
Karakteristik Wanita yang Bekerja di Wilayah Perkotaan dan di Pedesaan Karakteristik Individu

Karakteristik individu adalah karakteristik yang melekat pada seseorang dan bersifat khas. Karakteristik individu tersebut berbeda antara wanita bekerja yang satu dengan yang lainnya. Karakteristik individu yang diteliti meliputi lima hal yaitu usia wanita bekerja, tingkat pendidikan formal, aktifitas pekerjaan, gaya hidup, dan pendapatan wanita bekerja.

\section{Usia Wanita Bekerja}

Wanita bekerja adalah wanita yang melakukan suatu kegiatan secara teratur atau berkesinambungan dalam suatu jangka waktu tertentu, dengan tujuan yang jelas yaitu untuk menghasilkan atau mendapatkan sesuatu dalam bentuk benda, uang, jasa maupun ide. Wanita bekerja yang dipilih berada dalam rentang usia antara 18 tahun sampai 60 tahun dan dalam keluarga wanita bekerja memiliki televisi sehingga wanita bekerja dapat menyaksikan iklan produk kecantikan di televisi. Berdasarkan uji statistik u-mann whitney terdapat perbedaan yang nyata antara usia wanita bekerja di perkotaan dan di pedesaan $(\mathrm{p}<0,05)$. Hal ini dapat dilihat dari perbedaan sebaran umur di wilayah perkotaan dan pedesaan yang cukup signifikan.

Tabel 1. Sebaran Responden Menurut Karakteristik Usia Wanita Perkotaan dan Pedesaan di Kota Bogor Tahun 2009

\begin{tabular}{lcccc}
\hline $\begin{array}{l}\text { Karakteristik } \\
\text { Usia }\end{array}$ & $\begin{array}{c}\text { Wanita bekerja di kota } \\
\text { (orang) }\end{array}$ & $\begin{array}{c}\text { Persen } \\
(\boldsymbol{\%})\end{array}$ & $\begin{array}{c}\text { Wanita bekerja di } \\
\text { desa(orang) }\end{array}$ & $\begin{array}{c}\text { Persen } \\
(\boldsymbol{\%})\end{array}$ \\
\hline Usia muda & 4 & 13.33 & 5 & 16.67 \\
Usia dewasa & 16 & 53.33 & 25 & 83.33 \\
Usia tua & 10 & 33.33 & 0 & 0 \\
\hline Total & $\mathbf{3 0}$ & $\mathbf{1 0 0}$ & $\mathbf{3 0}$ & $\mathbf{1 0 0}$ \\
\hline
\end{tabular}

\section{Tingkat Pendidikan Formal}

Berdasarkan 60 responden yang menjadi subjek penelitian ini ternyata terdapat perbedaan yang sangat jelas sekali dari tingkat pendidikan formal di desa dan kota. Untuk tingkat pendidikan rendah (tidak sekolah sampai Sekolah Dasar) di desa terdapat 27 responden dan di kota tidak 
terdapat wanita bekerja yang berpendidikan rendah. sedangkan tingkat pendidikan sedang (Sekolah Lanjutan Tingkat Pertama sampai Sekolah Lanjutan Tingkat Akhir) di desa hanya terdapat 3 responden dan di kota terdapat 20 responden, dan untuk tingkat pendidikan tinggi (pendidikan lanjutan setelah SLTA) di desa tidak ada yang berpendidikan tinggi, dan di kota berjumlah 10 orang. Berdasarkan uji statistik u-mann whitney terdapat perbedaan yang nyata antara tingkat pendidikan formal wanita bekerja di perkotaan dan di pedesaan $(p<0,05)$. Wilayah perkotaan memiliki tingkat pendidikan yang lebih tinggi, dibandingkan wilayah perdesaan.

Tabel 2. Sebaran Responden Menurut Karakteristik Tingkat Pendidikan Perkotaan dan Pedesaan di Kota Bogor Tahun 2009

\begin{tabular}{|c|c|c|c|c|}
\hline $\begin{array}{c}\text { Karakteristik } \\
\text { tingkat pendidikan }\end{array}$ & $\begin{array}{l}\text { Wanita bekerja } \\
\text { di kota (orang) }\end{array}$ & $\begin{array}{c}\text { Persen } \\
(\%)\end{array}$ & $\begin{array}{l}\text { Wanita bekerja } \\
\text { di desa(orang) }\end{array}$ & $\begin{array}{c}\text { Persen } \\
(\%)\end{array}$ \\
\hline Pendidikan rendah & 0 & & 27 & 90 \\
\hline Pendidikan sedang & 20 & 66.66 & 3 & 10 \\
\hline Pendidikan tinggi & 10 & 33.33 & 0 & 0 \\
\hline Total & 30 & 100 & 30 & 100 \\
\hline
\end{tabular}

\section{Gaya Hidup}

Berdasarkan data di lapangan terhadap wanita bekerja di wilayah perkotaan dan pedesaan. Terdapat perbedaan dalam melihat gaya hidup di wilayah desa dan kota. Penilaian gaya hidup dilakukan dengan melihat persentase besar pengeluaran wanita bekerja dalam memenuhi kebutuhannya untuk kecantikan. Hasil menunjukan perbedaan yang jelas antara gaya hidup perkotaan dan pedesaan. Berdasarkan uji statistik u-mann whitney terdapat perbedaan yang nyata antara gaya hidup wanita bekerja di perkotaan dan di pedesaan $(\mathrm{p}<0,05)$. Hal ini berarti terlihat perbedaan yang nyata dalam hal gaya hidup wanita bekerja di perkotaan dan di pedesaan dalam memenuhi kebutuhan akan kecantikan. Perbedaan dalam pemenuhan kebutuhan kecantikan untuk masyarakat desa dengan mengunakan produk yang terjangkau ataupun menggunakan jamu tradisional, wanita pedesaan pun tidak memiliki atau mengunjungi dokter kecantikan maupun pergi ke salon, berbeda dengan wanita perkotaan yang hamper tiap harinya menggunakan make-up, mengunjungi pusat kebugaran, perawatan salon maupun memiliki dokter kecantikan yang terpercaya.

Tabel 3. Sebaran Responden Menurut Karakteristik Gaya Hidup Perkotaan dan Pedesaan di Kota Bogor Tahun 2009

\begin{tabular}{lllll}
\hline $\begin{array}{c}\text { Karakteristik } \\
\text { gaya hidup }\end{array}$ & $\begin{array}{l}\text { Wanita bekerja } \\
\text { di Kota (orang) }\end{array}$ & Persen (\%) & $\begin{array}{l}\text { Wanita bekerja } \\
\text { di Desa (orang) }\end{array}$ & Persen (\%) \\
\hline Gaya hidup rendah & 4 & 13.33 & 0 & 0 \\
Gaya hidup sedang & 21 & 70 & 26 & 86.66 \\
Gaya hidup tinggi & 5 & 16.66 & 4 & 13.33 \\
\hline Total & $\mathbf{3 0}$ & $\mathbf{1 0 0}$ & $\mathbf{3 0}$ & $\mathbf{1 0 0}$ \\
\hline
\end{tabular}

\section{Aktifitas Pekerjaan}

Berdasarkan hasil yang didapat di lapangan, terdapat 16 orang wanita perkotaan yang melakukan aktifitas pekerjaan di dalam kantor, sedangkan untuk di desa tidak ada. Hasil untuk wanita perkotaan yang melakukan aktifitas 
pekerjaan berhubungan dengan publik terdapat 14 orang, sedangkan untuk pedesaan tidak terdapat wanita bekerja yang berhubungan dengan publik. Hasil untuk wanita yang beraktifitas di lapangan menujukan terdapat 30 orang wanita pedesaan yang seluruhnya bekerja di lapangan sebagai buruh tani setengah hari, dan tidak terdapat seorangpun wanita perkotaan yang bekerja di lapangan.

Tabel 13. Sebaran Responden Menurut Karakteristik Aktifitas Pekerjaan Perkotaan dan Pedesaan di Kota Bogor Tahun 2009

\begin{tabular}{lcccc}
\hline $\begin{array}{l}\text { Karakteristik aktifitas } \\
\text { pekerjaan }\end{array}$ & $\begin{array}{c}\text { Wanita bekerja } \\
\text { di kota (orang) }\end{array}$ & $\begin{array}{c}\text { Persen } \\
(\boldsymbol{\%})\end{array}$ & $\begin{array}{c}\text { Wanita bekerja } \\
\text { di desa (orang) }\end{array}$ & $\begin{array}{c}\text { Persen } \\
(\boldsymbol{\%})\end{array}$ \\
\hline $\begin{array}{l}\text { Pekerjaan di dalam } \\
\text { kantor }\end{array}$ & 16 & 53.33 & 0 & 0 \\
$\begin{array}{l}\text { Pekerjaan berhubungan } \\
\text { dengan publik }\end{array}$ & 14 & 46.66 & 0 & 0 \\
$\begin{array}{l}\text { Pekerjaan di lapangan } \\
\text { Total }\end{array}$ & 0 & 0 & 30 & 100 \\
\hline
\end{tabular}

Berdasarkan uji statistik U-mann whitney terdapat perbedaan yang sangat nyata aktifitas pekerjaan wanita bekerja di perkotaan dan di pedesaan $(\mathrm{p}<0,05)$. Hal ini berarti terdapat perbedaan yang sangat signifikan antara aktifitas pekerjaan antara wanita bekerja di perkotaan dan di pedesaan. Perbedaan terjadi karena semua wanita pedesaan bergerak di bidang pertanian

\section{Tingkat Pendapatan}

Hasil yang diperoleh dari penyebaran kuesioner di lapangan. Terdapat perbedaan yang jelas sekali dalam hal pendapatan yang diterima oleh suami istri dalam suatu rumah tangga setiap bulannya. Pendapatan dikelompoknya menjadi tiga kategori yaitu pendapatan rendah (< Rp.2.500.00,-), pendapatan sedang (Rp.2.500.000Rp.10.000.000,-), dan pendapatan tinggi (> Rp.10.000.000,-). Sebanyak 2 responden dengan menjadi buruh tani setengah hari dan mereka bekerja di lapangan (persawahan), sedangkan wanita perkotaan bekerja di sektor industri atau jasa yang menuntut mereka berpenampilan rapid an menarik. Wanita perkotaan bekerja di dalam ruangan maupun langsung berhubungan dengan publik. wilayah perkotaan berpendapatan rendah, 24 responden berpendapatan sedang, dan sebanyak 4 responden wilayah perkotaan berpendapatan tinggi. Sedangkan wilayah pedesaan, hasilnya sebanyak 2 responden wilayah pedesaan perpendapatan rendah, 25 orang berpendapatan sedang, dan 3 responden di wilayah pedesaan berpendapatan tinggi

Tabel 4. Sebaran Responden Menurut Tingkat Pendapatan Hidup Perkotaan dan Pedesaan di Kota Bogor Tahun 2009

\begin{tabular}{lllll}
\hline $\begin{array}{c}\text { Karakteristik } \\
\text { Pendapatan }\end{array}$ & $\begin{array}{l}\text { Wanita bekerja } \\
\text { di kota (orang) }\end{array}$ & Persen (\%) & $\begin{array}{l}\text { Wanita bekerja } \\
\text { di desa (orang) }\end{array}$ & Persen (\%) \\
\hline Pendapatan rendah & 2 & 6.66 & 2 & 6.66 \\
Pendapatan sedang & 24 & 80 & 25 & 83.33 \\
Pendapatan tinggi & 4 & 13.33 & 3 & 10 \\
\hline Total & $\mathbf{3 0}$ & $\mathbf{1 0 0}$ & $\mathbf{3 0}$ & $\mathbf{1 0 0}$ \\
\hline
\end{tabular}


Berdasarkan uji statistik U-mann whitney terdapat perbedaan yang sangat nyata jenis pendapatan rumah tangga di wilayah perkotaan dan di pedesaan $(\mathrm{p}<0,05)$. Hal ini berarti terdapat perbedaan pendapatan rumah tangga wilayah perkotaan dan pedesaan. Pendapatan berbeda karena jenis pekerjaannya berbeda, dimana wanita pedesaan bergerak di pertanian, wanita perkotaan di sektor industri atau jasa.

\section{Hubungan Karakteristik Sosiologis dengan Orientasi Tubuh Wanita Bekerja}

Karakteristik sosiologis adalah kondisi atau situasi yang berkaitan dengan keadaan di lingkungan sosial wanita bekerja. Karakteristik sosiologis wanita bekerja diketahui dengan melihat pengaruh berupa komentar, pendapat, atau kritikan dari lingkungan sekitar wanita bekerja terhadap penampilan wanita bekerja. Kategori penilaian dari komentar lingkungan sekitar dibedakan menjadi iya dan tidak. Semakin banyak wanita bekerja menjawab iya, maka lingkungan sosiologisnya turut berpengaruh dalam membentuk citra dirinya. Karakteristik sosiologis terbagi menjadi lingkungan keluarga, lingkungan kerja dan kelompok sosial.

\section{Hubungan Lingkungan Keluarga dengan Orientasi Tubuh Wanita Bekerja}

Berdasarkan hasil uji Korelasi Rank Spearman diperoleh nilai $-0,279$ artinya antara lingkungan keluarga dengan orientasi tubuh wanita bekerja memiliki hubungan yang negatif (nyata), semakin tinggi penilaian lingkungan keluarga terhadap penampilan wanita bekerja maka semakin rendahorientasi tubuh pada wanita yang bekerja. Hasilnya,wanita yang paling banyak bercitra tubuh negatif yaitu wanita yang menurut penilaian keluarga rendah $(72,22 \%)$.

Tabel 5. Sebaran Responden Menurut Penilaian Keluarga dan Citra Tubuh Wanita Bekerja di Kota Bogor Tahun 2009

\begin{tabular}{|c|c|c|c|c|c|c|}
\hline \multirow{2}{*}{$\begin{array}{l}\text { Karakteristik } \\
\text { penilaian keluarga }\end{array}$} & \multicolumn{4}{|c|}{ Citra tubuh (orang) } & \multirow{2}{*}{$\begin{array}{l}\text { Total } \\
\text { (orang) }\end{array}$} & \multirow{2}{*}{$\begin{array}{l}\text { persen } \\
(\%)\end{array}$} \\
\hline & Positif (+) & $\begin{array}{l}\text { persen } \\
(\%)\end{array}$ & $\begin{array}{l}\text { Negatif } \\
(-)\end{array}$ & $\begin{array}{l}\text { persen } \\
(\%)\end{array}$ & & \\
\hline $\begin{array}{ll}\text { Penilaian keluarga } \\
\text { rendah }\end{array}$ & 5 & 27.77 & 13 & 72.22 & 18 & 30 \\
\hline $\begin{array}{l}\text { Penilaian keluarga } \\
\text { tinggi }\end{array}$ & 18 & 42.85 & 24 & 57.14 & 42 & 70 \\
\hline Total & 23 & - & 37 & - & 60 & 100 \\
\hline
\end{tabular}

Lingkungan keluarga adalah kondisi atau situasi yang menggambarkan suasana di lingkungan keluarga wanita bekerja. Hal ini dibedakan berdasarkan interaksi wanita bekerja dengan penilaian dari pihak keluarga mengenai penilaian orang terdekat (Significant other) mengenai tubuhnya. Hasil yang didapat sebanyak 25 orang wanita bekerja perkotaan dan 17 orang wanita bekerja pedesaan berpendapat pengaruh keluarga sangat penting bagi mereka.

Peran keluarga saat proses sosialisasi yang dimulai sejak dini mengukuhkan bahwa bentuk tubuh yang langsing adalah tubuh yang diharapkan oleh lingkungan. Orang tua terpengaruh oleh berbagai iklan yang mengagung-agungkan tubuh langsing dan indah, sehingga mereka menjadi khawatir kalau tubuh anak perempuannya berkembang tidak seperti yang dipromosikan oleh media massa. Oleh sebab itu, seseorang akan terpengaruh oleh komentar atau penilaian keluarga mereka karena pengaruh orang yang berarti bagi individu (significant other ) keluarga akan mempengaruhi individu tersebut terhadap orientasi tubuhnya. 


\section{Hubungan Lingkungan Pekerjaan dengan Orientasi Tubuh Wanita Bekerja}

Lingkungan kerja adalah kondisi atau situasi yang menggambarkan suasana di lingkungan pekerjaan wanita bekerja. Lingkungan kerja meliputi tuntutan pekerjaan dan penilaian rekan kerja akan penampilan wanita bekerja. Tuntutan pekerjaan merupakan tekanan yang dirasakan wanita bekerja untuk melakukan sesuatu hal terkait dengan masalah penampilan sedangkan penilaian rekan kerja merupakan komentar atau pendapat dari rekan satu profesi mengenai penampilan wanita bekerja.

\section{Hubungan Tuntutan Pekerjaan dengan Orientasi Tubuh Wanita Bekerja}

Berdasarkan hasil uji Korelasi Rank Spearman diperoleh nilai $-0,952$ artinya antara tuntutan pekerjaan dengan orientasi tubuh wanita bekerja memiliki hubungan yang negatif(nyata), semakin tinggi tuntutan pekerjaan seseorang maka semakin rendah orientasi tubuh pada wanita yang bekerja. Data dilapangan menunjukan wanita yang memiliki citra tubuh negatif terbanyak yaitu wanita yang memiliki tuntutan kerja yang rendah $(62,06 \%)$.

Tabel 6. Sebaran Responden Menurut Tuntutan Pekerjaan dan Citra Tubuh Wanita Bekerja di Kota Bogor Tahun 2009

\begin{tabular}{lllllll}
\hline $\begin{array}{l}\text { Karakteristik tuntutan } \\
\text { kerja }\end{array}$ & \multicolumn{2}{l}{ Citra tubuh (orang) } & $\begin{array}{l}\text { Total } \\
\text { (orang) }\end{array}$ & $\begin{array}{l}\text { persen } \\
(\%)\end{array}$ \\
\cline { 2 - 6 } & Positif $(+)$ & persen $(\%)$ & $\begin{array}{l}\text { Negatif } \\
(-)\end{array}$ & persen (\%) & & \\
\hline $\begin{array}{l}\text { Tuntutan kerja rendah } \\
\text { Tuntutan kerja tinggi }\end{array}$ & 11 & 37.93 & 18 & 62.06 & 29 & 48.33 \\
\hline Total & 12 & 38.70 & 19 & 61.29 & 31 & 51.66 \\
\hline
\end{tabular}

Tuntutan pekerjaan merupakan tekanan yang dirasakan wanita bekerja untuk melakukan sesuatu hal terkait dengan masalah penampilan, seberapa besar tekanan yang dirasakan wanita bekerja untuk berpenampilan tertentu ditempat kerjannya akan semakin besar orientasi wanita tersebut terhadap orientasi tubuhnya. Tuntutan pekerjaan memang berpengaruh dalam penampilan seorang wanita bekerja, untuk memasuki lingkungan pekerjaan-pun ada kualifikasi tertentu yang mensyaratkan wanita berpenampilan menarik (Professional Beauty Qualification). Wanita dituntut berpenampilan menarik sebagai pencitraan positif dari karyawan perusahaan untuk meningkatkan citra perusahaan di masyarakat. Hal ini dapat diinterprestasikan bahwa untuk pekerjaan non-lapangan (tidak bekerja di sawah, kebun, atau ladang) wanita perkotaan cenderung dituntut lebih tinggi dalam hal tuntutan pekerjaan dibandingkan dengan wanita pedesaan yang bekerja di sektor pertanian.

\section{Hubungan Rekan Kerja dengan Orientasi Tubuh Wanita Bekerja}

Berdasarkan hasil uji Korelasi Rank Spearman diperoleh nilai $-0,604$ artinya antara penilaian rekan kerja dengan orientasi tubuh wanita bekerja memiliki hubungan yang negatif (nyata), semakin tinggi penilaian rekan kerja seseorang maka semakin rendah orientasi tubuh pada wanita yang bekerja. Data menunjukan wanita yang memiliki citra tubuh negatif yaitu wanita yang penilaian rekan kerjanya rendah $(64,10 \%)$. 
Tabel 7. Sebaran Responden Menurut Karakteristik Penilaian Rekan Kerja dan Citra Tubuh Wanita Bekerja di Kota Bogor Tahun 2009

\begin{tabular}{|c|c|c|c|c|c|c|}
\hline \multirow{2}{*}{$\begin{array}{l}\text { Karakteristik } \\
\text { penilaian rekan } \\
\text { kerja }\end{array}$} & \multicolumn{4}{|c|}{ Citra tubuh (orang) } & \multirow{2}{*}{$\begin{array}{l}\text { Total } \\
\text { (orang) }\end{array}$} & \multirow[t]{2}{*}{ persen $(\%)$} \\
\hline & Positif (+) & $\begin{array}{l}\text { persen } \\
(\%)\end{array}$ & $\begin{array}{l}\text { Negatif } \\
(-)\end{array}$ & $\begin{array}{l}\text { persen } \\
(\%)\end{array}$ & & \\
\hline $\begin{array}{l}\text { Penilaian rekan } \\
\text { kerja rendah }\end{array}$ & 14 & 35,89 & 25 & 64,10 & 39 & 65 \\
\hline $\begin{array}{l}\text { Penilaian rekan } \\
\text { kerja rendah }\end{array}$ & 9 & 42,85 & 12 & 57,14 & 21 & 35 \\
\hline Total & 23 & -- & 37 & - & 60 & 100 \\
\hline
\end{tabular}

Penilaian rekan kerja merupakan komentar atau pendapat dari rekan satu profesi mengenai penampilan wanita bekerja. Penilaian ini bisa berisikan kritik, pendapat, nasihat, atau celaan dari rekan kerja ditempat wanita itu bekerja terhadap penampilan atau tubuh wanita tersebut. Orang-orang yang termaksud kedalam rekan kerja meliputi atasan, rekan satu profesi, dan bawahan. Semakin tinggi jabatan orang yang berkomentar menurut responden, semakin tinggi pula orientasi tubuh responden tersebut. Perbedaan tempat kerja mempengaruhi pula wanita bekerja menilai tubuhnya, yang dalam penelitian ini wanita bekerja di perkotaan kebanyakan bergerak di industri dan jasa, sedangkan wanita bekerja di perdesaan bergerak dibidang pertanian. Hasilnya, wanita bekerja perkotaan cenderung lebih terpengaruh akan penilaian rekan kerja dibandingkan wanita bekerja di wilayah pedesaan.

Perbedaan pendapat mengenai rekan kerja disebabkan oleh suasana dan aktifitas pekerjaan wanita bekerja di lingkungan kerja. Untuk pekerjaan yang didalam ruangan dan berhubungan dengan publik kebanyakan besar memang menuntut wanita agar berpenampilan menarik sehingga saran, pendapat ataupun kritikan dari rekan satu profesi berpengaruh terhadap penampilan mereka ditempat kerja, sebaliknya dengan wilayah pedesaan yang sebagian penduduknya bergerak dibidang pertanian dan perkebunan, faktor rekan kerja tidak berpengaruh terhadap gaya penampilan mereka ditempat kerja.

\section{Hubungan Kelompok Sosial dengan Orientasi Tubuh Wanita Bekerja}

Berdasarkan hasil uji Korelasi Rank Spearman diperoleh nilai $+0,438$ artinya antara kelompok sosial dengan orientasi tubuh wanita bekerja memiliki hubungan yang positif (nyata), semakin tinggi kelompok sosial seseorang maka semakin tinggi orientasi tubuh pada wanita yang bekerja. Data dilapangan menunjukan, wanita yang mendapat penilaian kelompok yang rendah mengalami citra tubuh yang negatif $(68,18 \%)$.

Tabel 8. Sebaran Responden Menurut Pengaruh Kelompok dan Citra Tubuh Wanita Bekerja di Kota Bogor Tahun 2009

\begin{tabular}{|c|c|c|c|c|c|c|}
\hline \multirow{2}{*}{$\begin{array}{l}\text { Karakteristik } \\
\text { pengaruh kelompok }\end{array}$} & \multicolumn{4}{|c|}{ Citra tubuh (orang) } & \multirow{2}{*}{$\begin{array}{l}\text { Total } \\
\text { (orang) }\end{array}$} & \multirow{2}{*}{$\begin{array}{l}\text { persen } \\
(\%)\end{array}$} \\
\hline & Positif (+) & persen $(\%)$ & $\begin{array}{l}\text { Negatif } \\
(-)\end{array}$ & persen $(\%)$ & & \\
\hline $\begin{array}{l}\text { Pengaruh } \\
\text { rendah }\end{array}$ & 7 & 31.81 & 15 & 68.18 & 22 & 36.66 \\
\hline $\begin{array}{l}\text { Pengaruh } \\
\text { tinggi }\end{array}$ & 16 & 42.10 & 22 & 57.89 & 38 & 63.33 \\
\hline Total & 23 & -- & 37 & - & 60 & 100 \\
\hline
\end{tabular}


Dentifikasi kelompok sosial adalah bagaimana pengaruh orang lain dalam satu kelompok terhadap penampilan wanita bekerja di lingkungan sosialnya. Kelompok sosial yang berada dalam lingkungan sosial wanita bekerja yaitu arisan, pengajian, ataupun teman se-permainan. Dalam kelompok sosial individu akan membandingkan dirinya dengan orang lain, biasanya yang hampir serupa dengannya, kemudian individu akan mengevaluasi dirinya dengan subjek pembandingnya dan mulai melihat perbedaan atau kekurangan yang tidak sesuai dengan subjek pembanding. Dalam hal ini yang biasa dijadikan individu sebagai subjek pembanding adalah orang yang dikagumi individu, baik dari cara ia berjalan, berpenampilan maupun bentuk tubuhnya.

Penekanan masyarakat sendiri, selama ini mungkin tidak ada aspek dari penampilan mengalami kecemasan yang lebih hebat daripada masalah bentuk tubuh dan berat badan. Menjadi gemuk adalah hal terutama yang dipedulikan perempuan, sebagaimana kelangsingan merupakan aspek utama dari kecantikan fisik itu dilihat. Lingkungan sosial dalam hal ini kelompok sosialpun turut mempengaruhi wanita dalam menilai penampilan fisiknya. Kesadaran akan adanya reaksi sosial terhadap berbagai bentuk tubuh menyebabkan para wanita prihatin akan pertumbuhan tubuhnya apabila tidak sesuai dengan standar budaya yang berlaku dan lama kelamaan akan menurunkan rasa percaya diri seseorang sehingga ia-pun memiliki citra tubuh yang negatif.

Hubungan Faktor-faktor yang mempengaruhi orientasi tubuh wanita bekerja wilayah perkotaan dan pedesaan yaitu:

1. Hubungan karakteristik individu (Usia, Tingkat pendidikan formal, Gaya hidup, aktifitas pekerjaan, dan tingkat pendapatan) memiliki hubungan positif (nyata) terhadap orientasi tubuh wanita bekerja. Artinya, semakin tinggi Usia, Tingkat pendidikan formal, Gaya hidup, aktifitas pekerjaan, dan

\section{Kesimpulan}

Wanita bekerja di wilayah perkotaan dan pedesaan memiliki karakteristik individu yang berbeda. Perbedaan ini dilihat dari usia responden, tingkat pendidikan formal, gaya hidup akan kecantikan, aktifitas pekerjaan, dan pendapatan keluarga. Dari usia, kebanyakan responden wilayah perkotaan dan pedesaan berada pada usia dewasa antara 29 tahun sampai 45 tahun. Tingkat pendidikan formal wilayah pedesaan cenderung rendah (tidak sekolah sampai SD), sedangkan kebanyakan responden wilayah perkotaan memiliki tingkat pendidikan formal sedang (SLTP-SLTA). Gaya hidup akan kecantikan wilayah perkotaan dan pedesaan umumnya berada di rentan gaya hidup sedang yaitu antara 2 persen sampai 14 persen dari total pendapatan keluarga. Dilihat dari aktifitas pekerjaan, wanita bekerja wilayah perkotaan memiliki aktifitas di dalam ruangan dan berhubungan langsung dengan publik, karena sebagian besar dari mereka bekerja di sektor industri, lain halnya dengan wanita bekerja wilayah pedesaan, semua wanita melakukan aktifitas bekerjanya di lapangan, karena mereka semua bergerak pada sektor pertanian yaitu buruh tani setengah hari. Sedangkan untuk tingkat penghasilan rumah tangga, kebanyakan responden baik wilayah perkotaan dan pedesaan menempati tingkat pendapatan sedang, yakni untuk wilayah perkotaan antara Rp. 2.500.000,- sampai dengan Rp.10.000.000,- dari pendapatan sebulan, dan wilayah pedesaan antara Rp.800.000,- sampai dengan Rp.1.300.000 dari pendapatan sebulan.

tingkat pendapatan maka semakin tinggi pula orientasi tubuh wanita bekerja.

2. Hubungan karakteristik lingkungan sosial (Lingkungan keluarga, Lingkungan kerja, dan Kelompok sosial) dengan orientasi tubuh wanita memiliki hubungan yang positif (nyata). Artinya, semakin tinggi pengaruh karakteristik lingkungan sosial dalam menilai individu atas penampilannya maka akan semakin tinggi pula orientasi tubuh wanita bekerja. 


\section{Daftar Pustaka}

Andika J. 2008. Hubungan Keterdedahan terhadap Media Massa dengan Pengetahuan tentang Kebijakan Pemerintah mengenai Flu Burung (Kasus pada Mahasiswa Fakultas Peternakan Institut Pertanian Bogor). Skripsi. Bogor(ID): Bogor

Arief AS. 2001 Perspektif Gender dalam Representasi Iklan. Jurusan Desain Komunikasi Visual. Fakultas Seni dan Desain - Universitas Kristen Petra.Yogyakarta

Bachtiar Aly. 2009. Kompetisi pencitraan. Jakarta(ID): Harian Seputar Indonesia.

Goenawan F. 2007. Ekonomi Politik Iklan Di Indonesia Terhadap Konsep Kecantikan. Jurnal Ilmiah SCRIPTURA. 1(1) Januari 2007.

Melliana A. 2006. Menjelajah Tubuh, Perempuan Dan Mitos Kecantikan. Yogyakarta(ID): LKIS.

Munfarida E.2007. Genealogi Kecantikan. Jurnal Ilmiah SCRIPTURA.5(2). 